\title{
Media Licensing, Convergence and Globalization
}

\author{
Robert Horvitz \\ Director, Open Spectrum Foundation \\ http://www.openspectrum.info \\ Email: bob@openspectrum.info
}

For the conference

"RE:activism: Re-drawing the Boundaries of Activism in a New Media Environment"

14-15 October 2005

Budapest, Hungary

\begin{abstract}
"The virtually universal licensing of all active subjects in the market of communications services is an out-of-date approach, that complicates work both of communications service operators and of state departments. In the Russian Statute On Licensing of Certain Types of Activity of 1998 it is fairly established, that licensing (as one of the most rigid forms of state control) makes sense only if all other mechanisms of control are inapplicable or extremely inefficient...” (Media Law and Policy Institute, Moscow, 2002)
\end{abstract}

In the summer of 2003, I had the pleasure of giving a seminar for 22 diplomats from Eastern Europe, to help them prepare for the first World Summit on the Information Society (WSIS). ${ }^{1}$ Most of them were chosen to attend WSIS for reasons other than their knowledge of topics on the agenda, so this was basically a UN-backed "crash course" on the issues dealt with in the draft WSIS Declaration of Principles and Action Plan.

During our discussion, one participant happened to mention that he thought websites offering streaming video should be licensed as TV stations. He justified this with the familiar recommendation by international experts that regulators should adopt a "technology neutral" approach it should not matter if the content is in analog or digital format, or delivered by wire or wirelessly. My counterargument - that broadcast licensing was a way to ration an inadequate number of radiofrequency channels and since the Internet has no channel shortage, there is no need for licensing - fell on deaf ears. In his country - as in many of the countries represented in this seminar - broadcasters need two licenses: one for a radiofrequency channel, and one to offer the public a program service. The latter is a kind of trade license, similar to what restaurants and transport companies need. It has nothing to do with channel scarcity and apparently that was the kind of license he had in mind.

I had already seen ${ }^{2}$ how the need to obtain parallel licenses from different government offices can lead to bribe-seeking delays and deadlocks when each agency makes its licensing decision contingent on the other agency's action. But everyone in the WSIS seminar saw dual licensing as

\footnotetext{
1 "Diplomacy and Cyberspace," a 4-day seminar convened by the United Nations Institute for Training and Research (UNITAR) and the United Nations Department for Economic and Social Affairs (UNDESA) at the Italian Diplomatic Institute in Rome, 23-27 June 2003. I led the session on computer applications.

${ }^{2}$ From 1992 to 1995 I was the Soros Foundations' radio consultant for Eastern Europe and Central Asia.
} 
appropriate since different elements of the activity were involved. ${ }^{3}$ Indeed, they saw licensing as a step forward, since broadcasting was a state monopoly before 1989. In any case, they all agreed that websites with streaming media are online broadcasters which governments should license to ensure a "level playing field" with over-the-air broadcasters.

It was troubling to think that these seminar participants might be typical of the officials attending WSIS. Decisions reached at WSIS are not legally binding, but our discussion brought into focus the risks of media convergence in a time of globalization, when countries with radically different media traditions seek consensus on complex and culturally sensitive policy questions, and it led directly to the creation of the Open Spectrum Foundation. ${ }^{4}$ Organizing a global assembly to set media policy for all is a risk when the majority is biased toward overregulation. Broadcasting is especially constrained in virtually all countries, both in terms of content and the number of stations allowed to operate. If it were to become the regulatory model for electronic communications in general, it would be most unfortunate - and not at all inconceivable:

- Several Asian countries - Australia, China, Singapore and Vietnam, among others already license Internet sites as a new kind of broadcasting. ${ }^{5}$ Asian influence on net policy and governance is sure to grow in coming decades.

- In 1996, the European Parliament adopted a new definition of "television broadcasting" in order to extend the "Television Without Frontiers" (TWF) Directive to electronic publishing, the Internet and other media services. ${ }^{6}$ The new definition was rejected in 1997, but the "Directive is currently undergoing review and will eventually be amended..." (EuroActiv.com, 2005) According to Intellect, the trade association for the telecommunications, information technology and electronics industries in the UK, recent proposals to update the TWF Directive "would have the effect of bringing almost all audio-visual content within the scope of EU broadcast regulation."7 (Intellect 2005) The new draft TWF Directive is supposed to be published by the end of this year.

\footnotetext{
${ }^{3}$ In some of the countries represented in this seminar, the service elements are actually provided by separate entities. Antenna Hungaria, for example, operates transmission centers for all broadcasters in the country (Tender for Antenna Hungaria 2005). But the dangers of dual licensing are well-described in "A Law That Can Stamp Out the Last Vestiges of Independent Radio and TV in Ukraine." (Yavorsky 2003)

${ }^{4}$ Founded in May 2005, the Open Spectrum Foundation is registered in Amsterdam as a nonprofit organization working to increase license exempt access to the radiofrequency spectrum, particularly in developing countries. The core idea of "open spectrum" is that "politeness" and "dynamic adaptivity"can now be built in to low-cost radio equipment, making it easy for large numbers of untrained users to share a band without the need for governments to micro-manage their access.

5 Australia's "Broadcasting Services Amendment (Online Services) Act" (1999) put "online services" into the framework of the country's broadcasting law - regardless of whether streaming media are involved. China requires websites with streaming media to have an "Internet Audio/Visual Program Transmission License" (Government of the PRC 2004) while sites which offer news require authorization from the State Council Information Office (Government of the PRC 2000). According to Reuters, "Registration was a feature of rules imposed earlier this year aimed at not-for-profit Internet activities, such as personal Web sites and blogs... [The] next few months should see an extension of regulations to mobile phone media, such as text messages..." (Young and Beck 2005) The Internet in Singapore is governed by rules in their "Broadcasting (Class Licence) Notification" (2001). For Vietnam, see the "Regulation on the management and licensing of information provision and website establishment on the Internet" (2002).

6 The new definition of a "television programme" adopted by the European Parliament was to be "an animated or non-animated sequence of images which may or may not be accompanied by sound." (ICRT,1996) Thus, any media object containing at least two images would have constituted a "television programme" for the purposes of the TWF Directive. Fortunately, the final draft of the amendments omitted that definition.

7 From Intellect's written response to the EC's "Public Consultation on the Modernisation of Rules of Audiovisual Services" (2005).
} 
- The criminal code of the United States says: "Whoever utters any obscene, indecent, or profane language by means of radio communication shall be fined under this title or imprisoned not more than two years, or both." 8 (18 U.S.C. 1464) Nonbroadcast applications of radio have grown dramatically since this law was first enacted ${ }^{9}$ so the catalog of communications subject to its penalties has grown, too. Case law has clarified that sanctions against "indecent" and "profane" radio speech must focus on transmissions that a young person could tune to inadvertantly while using equipment available for purchase by the general public. That is an over-simplification enforcement is actually more gerrymandere ${ }^{10}-$ but the point is that many radio signals fall into that category, not just broadcasts - amateur radio conversations, baby monitors, walkie-talkies, perhaps even unencrypted VoWiFi. Content restrictions originally applied to a small set of wireless services might become the new norm as wireless becomes ubiquitous and informal personal communications succeed public broadcasts as the most common use of spectrum. Note, too, that many countries use the same test - the possibility of accidental access by minors - to justify the imposition of broadcast-like controls on Internet sites even when radio communication is not involved.

- Most people believe and seem to accept that broadcasting is regulated for reasons other than preventing interference or rationing scarce channels. Ninety-five percent of the people surveyed recently in the UK, for example, think TV is regulated to protect the public and especially children from "harmful content" (Ofcom Residential Tracker 2004, cited in Richards 2005) That rationale is not specific to any technology.

Ed Richards, who gave the Ofcom Annual Lecture at the Westminster Media Forum a few months ago in London, framed the issue clearly:

"If we seek a consistent approach, in a world where distinctions according to different distribution mechanisms become less and less practical, then the question is do you regulate up to the highest common factor or regulate down to the lowest common denominator? Do television standards apply to all content, or do the absence of standards on the internet apply to all television and radio? In a world where significant numbers have video capable broadband access, the question really can be posed as starkly as that." (Richards 2005)

Content regulation is an issue of vital importance, of course, but our primary concern here is with licensing, as it embodies the notion that individuals need permission from the national government to use a specific channel for communication. Withholding permission can be used to censor, coerce or punish; the mere possibility of losing permission induces self-censorship. (Weare, Levi and Raphael, 2001) Licensing is a power that is easily abused, creating opportunities for corruption. (People's Daily 2003; Informa-tico.com 2005) As Morris Ernst said nearly 80 years ago (1926), "So long as the [Government] can determine which individuals shall be endowed with larynxes it does not need additional power to determine what shall be said."

\footnotetext{
${ }^{8}$ The laws of many countries do not distinguish between "obscene" and "indecent" but in the US the ban on "indecent" radio speech is significant because the First Amendment supposedly protects the right of adults to access "indecent" content - without that right extending to "obscene" content. (Lackman 2004) .

9 The wording of 18 U.S.C. 1464 derives from Public Law 632 (the Radio Act of 1927).

${ }^{10}$ For a current statement of US policy on indecent radio speech, see US Federal Communications Commission 2005. A more detailed but less current - and strikingly different - description of the policy on "Obscene, Profane and Indecent Broadcasts" is found in US Federal Communications Commission Enforcement Bureau 2004.
} 


\section{Authority to license: where does it come from?}

It is not self-evident where the right to license communications comes from. Details of the earliest precedents are lost and more recent examples shade into neighboring fields like trade licenses, intellectual property licenses, professional certification, etc. Constitutions often confer such rights, but just as often they merely legitimize powers assumed during the pre-constitutional stages of national development. There are, in fact, odd discrepancies in the way media are treated in the laws and customs of different countries, and these treatments have changed drastically over time (McIver and Birdsall 2002, Poole 1983). Therefore, no aspect of media regulation can be considered inevitable or immutable. Licensing emerged from specific historical processes, events and decisions - and a close study of these might suggest counter-processes to encourage delicensing. It is beyond the scope of this paper to explore licensing comprehensively but some historical highlights provide surprising and potentially useful insights.

Religious leaders have - perhaps too often - taken their personal revelations of God's Will and Plan as authority for "the suppression of dangerous books and the prevention of corruptive reading... Popes as well as councils, bishops no less than synods, considered it then, as always, their most sacred duty to safeguard the purity of faith and to protect the souls of the faithful by condemning and forbidding any dangerous book." (Catholic Encyclopedia, 1913) The invention of the printing press around 1450 made this task more difficult - and facilitated the spread of Protestant ideas. It was largely to combat Protestantism that the licensing of publishers became common in Europe. ${ }^{11}$ (Eisenstein, 1980) The first press licensing law seems to have been based on existing measures for regulating guilds and trades, though modified to enable the Crown to block certain content at will:

"[T] he first copyright law of 1476, the year William Caxton introduced the printing press in England, was a licensing law requiring printers to inscribe their name, location and titles of works they wanted to print on a register. If approved for publication, the Crown granted a copye to the printer. The rights flowing from this copye constituted 'copyright'... Henry VIII and his successors issued more and more proclamations against heretical or seditious books. The most important was issued in 1538...which made it necessary to secure a license from the Privy Council or 'the Star Chamber' of the King before printing or distributing any book...” (Chartrand, 2000)

The use of licensing in England to grant rights and restrict content was not limited to publishing:

“...licensing of commercial [theaters] and vetting of scripts was in place by the time of Elizabeth I [1558-1603]. Stage works were subject to pre-production censorship by the Lord Chamberlain (an officer of the Royal Household) under the Stage Licensing Act 1737, an enactment that with amendments remained in force until 1968." (Caslon Analytics 2005)

Cinematograph Acts 1909 and 1952 authorized local authorities in England

“...to require a licence to be taken out before any premises can be used for showing films to the public. Intended originally to cover fire and other safety regulations, these provisions have long since been used to justify local censorship...

"[The] Video Recordings Act was passed in 1984... this Act revived in full the principles of the Licensing Act that expired in 1695 [after which] the doctrine of prior restraint was to vanish from these islands for the next 289 years. Then it reappeared... [The British

\footnotetext{
11 The licensing of presses and publications is now widely considered a violation of human rights (Lahav 1985, Coliver 1993, Karlekar 2005) although it remains common in Arab countries. (Stanhope 2003)
} 
Board of Film Classification] now has the duty and the power to examine every item released on video, excepting a few of a scientific or educational nature, and to see whether it is fit for 'viewing in the home'... Of those not judged fit it is to insist on the necessary alterations. Those judged altogether unfit are to be refused a licence... Anyone involved in the distribution of an unlicensed tape is liable to a fine not exceeding $£ 20,000 \ldots$. (Gabb 1992)

The role of licensing in telegraphy is rarely discussed, so few people appreciate how little it had to do with the technical characteristics of the medium, and how much with notions of national security. What each country learned from the local growth of telegraphy - and from their neighbors' experience - influenced later stages of media evolution. According to Wallsten (2001),

"The first telegraph systems were optical, not electrical, and came into widespread use in Europe in the late 18th century. An optical telegraph system is essentially a series of stations, each equipped with a visual signaling system, placed as far apart as one could see with a telescope. At each station a lookout would watch the neighboring station through a telescope, read the message being signaled, and then relay it to the next station. The French War Department began building an optical telegraph network in 1794, and by 1842 operated a 300,000-kilometer network. The War Department did not allow public access to the network. In 1833 a private firm opened an optical telegraph to the public, but the French government shut it down and in 1837 declared telegraphy to be a state monopoly. This law was then applied to the state's electrical telegraph, which first opened in 1845. The public did not have access to telegraph lines until 1850. (Holcombe 1911)...

"Throughout Europe the relationship between the state and the telegraph system would become one of the most important elements determining the state's approach to telephony. Webb (1910, p.14) succinctly summed up the general story of Europe's initial experience with the telephone: "The telephone was taken to the Government Telegraph departments and offered for sale, but the Telegraph departments declined to take the risk of developing a totally new business. At the same time, however, they assumed [regulatory] control over the telephone and issued licenses to companies formed to exploit the new invention, these licenses being generally for restricted periods and surrounded by the most onerous conditions." Then, once it became clear that the public did, in fact, value telephone service, the government telegraph agency took it over." (Wallsten 2001: 2-3)

In the United States, two organizational models were considered for Samuel Morse's electric telegraph: a government monopoly like the post office; or a private business like the railroad. Morse preferred the postal model. In a letter to Congress in 1844 he wrote that the telegraph "is an engine of power, for good or for evil, which all opinions seem to concur in desiring to have subject to the control of the Government, rather than have it in the hands of private individuals and associations..." (Prime 1875: 507) Morse offered the US Post Office the exclusive right to operate a nationwide telegraph network, but the Postmaster General was not interested. He reported to Congress that telegraphy could never be profitable "under any rate of postage..." (Prime 1875: 510-511) As a result, Congress, predisposed toward private enterprise anyway, declined Morse's offer. ${ }^{12}$

\footnotetext{
${ }^{12}$ How different the history of telecommunications might have been if the Postmaster General's assessment of the telegraph's economic potential had been accurate! Telegraphy would have become a government monopoly in the United States. Telephony and "wireless telegraphy" probably would have followed that precedent. Without a commercial phone network, the emergence of commercial broadcasting networks would have been delayed, perhaps indefinitely (AT\&T created the first broadcasting station supported by the sale of advertisements in 1922). (Banning 1946) The public might never have been allowed to attach their own equipment to a government-owned phone network, as became possible after the Carterfone
} 
It seems not to have occurred to the US Government to license the commercial networks that Morse and the entrepeneurs who bought his equipment wanted to build. That helped the technology to spread more rapidly in the US than in other countries. However, permissions were still needed from property owners and different layers of government for right-of-ways to install the wires. Problems getting right-of-ways increased as the number of telegraph companies increased, leading to passage of the Post Roads Act of 1866 (US Rev. Stats. § 5263). This granted any telegraph company the right to put lines "through and over any portion of the public domain of the United States, over and along any of the military or post roads...and over, under, or across the navigable streams or waters" so long as the lines did not interfere with traffic or navigation. But to take advantage of these rights, the telegraph companies had to register with the Postmaster General, agree to interconnect with each other, and treat all customers equally (except for the federal government, which was to get preferential treatment). Requiring telegraph companies to register if they wanted to take advantage of this "federal franchise"13 was a small step toward licensing. Setting conditions that they interconnect and act as "common carriers" was regulation. ${ }^{14}$

Because telegraphy was to be used in business - was itself a business - and telegraph wires crossed state boundaries, Congress's authority to enact such a law was said to come from the "commerce clause" of the US Constitution. ${ }^{15}$ However, since most right-of-ways were essentially local (intrastate) Congress may have stretched its authority somewhat. It is also odd that they did not see an analogy between telegrams and newspapers. Both were written forms of communication involving "interstate commerce." The synergy - and rivalry - between these media was obvious as telegraphy revolutionized and reorganized the newspaper business. So why did the First Amendment shield newspapers from federal regulation but not telegraphy? (Pool 1983: 91-100) Was the Post Roads Act compatible with the Constitution because telegraph companies did not have to opt in?

Following the French rather than the American example, governments across Europe built stateowned telegraph networks during the 1850s. Most - but not all - were granted monopoly rights. The Scandinavian countries were notable exceptions: they encouraged private firms to compete in the deployment of telegraph lines. (Wallsten 2001: 3) However, a crucial aspect of the European approach was that when a state did not monopolize telegraphy, the concessions they awarded went only to domestic firms. As a foreigner, even Morse was excluded in the countries where he had a patent. (Prime 1875: 673-684) Unfortunately, this economic nationalism provoked the US Government to start licensing undersea cables terminating on American shores - without any legislative mandate to do so:

"[In] 1879, there was a minor fracas about submarine cables between the United States and a French cable company which had a franchise from the French government. The French company owned land on Cape Cod and planned to connect France with its private property in the United States. However, the French company "prohibited any American company from a corresponding right to land cables in France.' (Clark 1931 cited in Feldman 1975: 6) There had been no Congressional action on a foreign cable company

decision, so we might never have opened the cornucopia that includes cordless phones, fax/answering machines, data modems, etc. And without a private monopoly, there would have been no antitrust argument to cause the breakup of AT\&T in the 1980s, which induced other countries to demonopolize and privatize their telephone systems.

13 The phrase "federal franchise" came from a right-of-way case in 1867: Western Union v. Lakin, (53 Wash. 326, 101 Pac. 1094)

${ }^{14}$. Regrettably, we must skip over the issue of governments regulating the content of telegrams and the use of encryption in order to keep our focus on licensing.

15 "The Congress shall have Power To regulate Commerce with foreign nations and among the several States, and with the Indian Tribes...” Article I, Section 8, Clause 3 (US Constitution). 
landing on United States territory. President Grant exercised his 'executive function' in regard to the proposed action of the French cable company, and the French were not allowed to lay the cable on the cape. (Schreiner 1924 cited in Feldman 1975: 6)

"After that it was assumed a license from the President was needed for the landing and operation of submarine cables connecting the United States with foreign countries..." (Feldman 1975: 6)

The different approaches to telegraphy in Europe and America encouraged more initial diversity in European telephony than might be expected from the ubiquitous state monopolies which came later. Wherever there was no monopoly, franchises, laws and licensing were used to create varied market structures. According to Wallsten (2001: 3-7):

"Private firms - usually subsidiaries of the Bell Telephone Company - were the first to introduce telephony in Europe, as few governments anticipated the incredible demand for the technology... Several governments, whose telegraph departments viewed the telephone as just a 'scientific toy,' at best (Webb 1910), including Britain, Austria, Belgium, and France gave private concessions in the early 1880s (Bennett 1895).

"The high public demand for telephony soon became apparent, and state telegraph agencies saw a potential threat to their revenues. Laws that granted the state the right to control the telegraph were quickly extended to include the telephone in order to protect the telegraph. Austria and Belgium nationalized its private providers soon after granting concessions, and France took over all private exchanges by force in 1889 when the firms refused to hand over their assets (Bennett 1895). Some countries that had not yet allowed any substantial telephone investment, including Bulgaria, Germany, Switzerland, and Luxembourg established state-owned monopolies...

"Spain began with a remarkably open approach to telephony. An 1884 law made telephony the exclusive domain of the government, but the state reversed itself in 1886, declaring that "so long as the telephonic service is administered by the State it can never develop and attain the proportions demanded by the necessities of modern life..." (Bennett 1895, p. 323). In a move ahead of its time, Spain auctioned off concessions, where companies bid on the royalty they would pay the state... The state ultimately granted 35 concessions... Unfortunately, the state also decreed that at the end of the 20year concessions the entire system would revert to the state without compensation (Bennett 1895)...

"Sweden had no legal monopoly on telegraph, and the Bell company opened exchanges in Stockholm, Gothenburg, and Malmo in 1881. Local cooperatives began setting up almost immediately thereafter (Casson 1910), and by 1920 Sweden had almost 200 private telephone networks (Andersson-Skog 2000)... Parliament, apparently concerned about the dangers of monopoly, until 1918 prohibited the state firm from buying private firms (Andersson-Skog 2000)...

"The Danish government initially stayed out of telephony altogether, and Bell opened the first exchange in Copenhagen in 1880... (Bennett 1895). While the state possessed a legal right to a monopoly in telegraph and telephones, it allowed municipalities and other local authorities to grant private concessions as they wished... The Norwegian story is similar...”

Unlike Morse, Alexander Graham Bell did not want the US Government to build a monopoly on his invention. But like the telegraph, the American "Bell Telephone System" was launched without being subject to federal licensing. Unable to attract enough capital to build a nationwide 
network himself, Bell offered local franchises authorizing others to use his patented equipment. Those franchises became a commercial kind of license:

"In each part of the country, local agents and entrepreneurs established their own operating companies, and then contracted with Bell in Boston for an exclusive right to lease its telephones and offer telephone service in their own respective areas. In 1880, four years after the telephone's invention, there were over one hundred such companies, offering telephone service in 998 American cities and towns. American Bell owned stock in several of these undertakings... but many more were the product of local capital and local enterprise alone." (MacDougall, 2005)

The mosaic of franchises broke down after Bell's patent expired in 1894, and the rate at which new telephone companies were formed accelerated. "The most important legal issue to come up was that of intercompany licensing, specifically the refusal of licenses to competing telephone companies... By 1902, 451 of the 1002 cities that had phone service had two or more companies providing it." (Pool 1983: 101-102) Companies used whatever tricks they could to stop new competitors from invading their territory. Companies serving the same locale generally did not interconnect, lest they increase the value of the their competitor's network.. Some municipalities forbade interconnection, fearing that the local phone companies would form a cartel. But without interconnection, each company's subscribers could not call the subscribers of other networks unless the subscribers had multiple phones from competing networks. ${ }^{16}$ Was it better to have two or more non-interconnecting telephone companies, or a price-fixing local monopoly and no alternative for dissatisfied customers? Differences of opinion emerged since both options had disadvantages. US cities and states turned to licensing to control the number of phone companies operating in specific locales, and to regulate their behavior toward customers and each other. (Pool 1983: 102) Telephone licensing in the US was thus a bottom-up response to market problems at the local level - problems that had previously been suppressed by the franchising of Bell's patent.

\section{Radio}

Radio began as "wireless telegraphy” so it inherited much of telegraphy's political and regulatory baggage:

"The whole tendency of radio development has been in the direction of increasingly rigid control by patriotic politicians, who have been almost literally sitting on the doorsteps of the laboratories waiting for the technicians to appear with their inventions. It may have been to radio's advantage in a purely physical sense that it came into existence during the period of intense national rivalry which preceded the...war of 1914-1918, but the coincidence meant that radio became identified from the start with patriotic service to the state. No other means of communication provoked intervention by the state as quickly as did radio." (Riegel 1934: 38-39)

It is significant that agreement at the international level (establishing government responsibility for licensing radio stations) was initiated not to control interference but to reign in the Marconi Wireless Telegraphy Company Ltd., which had been founded in England "to establish a worldwide monopoly in radio telegraphy." (Howeth 1963: 20) Abroad, Marconi was viewed with suspicion as an agent of British imperialism. So as with wire telegraphy, national economic rivalries triggered the regulation of wireless telegraphy:

16 A US Supreme Court decision in 1899 found that the Post Roads Act of 1866 did not apply to telephone companies (Richmond v. Southern Bell Telephone and Telegraph Co., 174 US 761, 43 L.ed. 1162, 19 S.Ct. 778) (Pool 1983:100) 
"Prince Henry of Prussia, brother of the German Kaiser, was returning to Germany, in the S. S. Deutschland, after a visit to the United States [in 1902]. Soon after sailing, he desired to send President Roosevelt a radio message thanking him for the numerous honors and courtesies which had been accorded him. The Deutschland transmitted this message to the Marconi station at Nantucket, but that station refused to accept it because the ship was fitted with Slaby-Arco radio equipment. The irate Prince brought the matter to the attention of his brother. Kaiser Wilhelm thereupon instructed his government to initiate action in an attempt to establish international control over radio communications." (Howeth 1963: 71)

This incident led to the "International Radiotelegraphic Convention" drafted in Berlin in 1906 and modified at a followup conference in London in 1912. The Convention established the principle of national sovereignty over frequency use on a country's territory and on their ships at sea. ${ }^{17}$ (International Radiotelegraphic Convention 1912)

The Radio Act of 1912 was the US's legislative response to the Convention. It said all stations under US jurisdiction at sea or engaged in "commercial intercourse among the several states, or with foreign nations...or where interference would be caused thereby with the receipt of messages or signals" must be licensed by the Department of Commerce. The aim of licensing was to "minimize interference," but the Commerce Secretary could not refuse to issue a license unless the applicant was already causing interference. ${ }^{18}$ Stations not engaged in interstate or foreign "commercial intercourse" did not need licenses, nor did stations whose signals could not cross a state border or interfere with out-of-state signals. Amateurs on land were relegated to the band above $1500 \mathrm{kHz}$ - considered practically worthless at the time - while military users - and later, commercial broadcasters - were assigned frequencies below $1500 \mathrm{kHz}$. (Pub.Law-264 1912).

This rather finicky set of conditions resulted from the combination of the International Radiotelegraphic Convention, the US Constitution's First Amendment and the "commerce clause." That combination left gaps in federal authority, most notably for noncommercial and intrastate radio communication. These gaps were later widened by legal decisions stripping the Commerce Department of authority to enforce the Radio Act as well as the right to assign channels to specific licensees. ${ }^{19}$ That unleashed a flood.of new higher-powered stations into channels that were already saturated, but the broadcast band could not be expanded without encroaching on the frequencies allocated to amateurs - and there were many more them than broadcasters. ${ }^{20}$ With the Commerce Secretary unable to refuse a license application, assign frequencies, punish overpowered stations or expand the broadcast band, chaos ensued - though some say it was deliberately orchestrated to justify limiting the issuance of new licenses, thereby protecting

\footnotetext{
${ }^{17}$ A modern and extreme example of this principle is found in Honduras' framework law for the telecommunications sector which says, in Article 9, "El espectro radioeléctrico es un recurso natural de propiedad exclusiva del Estado..." (The radioelectric spectrum is a natural resource which is the exclusive property of the State...) (Government of Honduras 1995)

18 The must-license rule led to the imposition of power limits and time-sharing arrangements for channels. (Hazlett 2002: 353)

${ }^{19}$ Circumstantial evidence strongly suggests that the Commerce Secretary sabotaged his own authority in order to create chaos in the airwaves and thus pressure Congress into quickly passing a new and tougher radio law: "The Secretary of Commerce openly invited broadcasters to challenge his power to regulate radio. He lost the resulting case. [U.S. v. Zenith Radio Corp., 12 F.2d 614 (N.D. Ill. 1926)]. The Secretary of Commerce then refused to appeal the decision, on advice of a public opinion offered by the Acting Attorney General...despite its conflict with a previous case decided by a higher court." (Hazlett 2002: $355)$.

20 "By 1919 about four thousand amateur stations existed, four or five times the total of commercial and military stations...” (Fagen 1976: I,384 cited in Pool 1983: 112)
} 
existing licenseholders from further competition. ${ }^{21}$ (Hazlett 2001: 351-357) The decision to toughen licensing requirements thus seems to have been based more on economic and political considerations than technical ones.

Pool (1983: 114-115) points out that research was already underway in the 1920s that would soon vastly expand the spectrum of exploitable radio frequencies and overcome the shortage that seemed to justify restrictive licensing. But Congress and the courts were not impressed by the policy implications of this new research, nor was any other government. The conclusion that spectrum was inherently scarce - and always would be - was widely accepted from that time onward:

“...in 1923 and 1924 [radio amateurs] achieved transmissions at $3 \mathrm{MHz} . .$. In 1924 the British Marconi Company ran experiments at frequencies of $10 \mathrm{MHz}$, and by 1926 it started a telegraphic service for Canada at 10-20 MHz. In 1925 it was studying frequencies of $150 \mathrm{MHz} .$.

"Some news of the prospective availability of additional frequencies did leak through to the political authorities. As early as 1924, [Secretary of Commerce] Hoover urged passage of a temporary radio act until there was time to study the implications of new developments in the radio art... Yet even the 'great engineer,' Hoover, saw no short-term prospects of a technical fix...."

The descent into airwave anarchy in 1926 stoked demand for a quick legislative fix. It foreclosed the option of waiting until affordable equipment was available for widespread use of higher frequencies, even though that would have ended the apparent frequency shortage and kept radio licensing a minor speed-bump. Instead, the Radio Act of 1927 and the Communications Act of 1934 were enacted successively, imposing tighter licensing rules. ${ }^{22}$

Thus, the policy of issuing radio licenses to virtually anyone in the US who wanted one was replaced by an obligation to determine whether a proposed station was necessary, convenient and in the public interest. As Pool noted, "A prohibition on the establishment of instruments of communication unless the government concludes they are required is all that the most authoritarian regime could want as public policy." (1983: 106)

We have dwelled so long on US radio law because, despite Pool's criticism, this was and still is one of the most liberal radio regulatory traditions in the world. ${ }^{23}$ Other countries generally have more restrictive licensing policies, ${ }^{24}$ so it is no accident that leadership in the liberalization of

21 Official contemporary accounts in the US indicate that from 1921 to 1926, the development of broadcasting was "orderly," but the situation deteriorated quickly after the events described in note 19 (supra).

22 The radio provisions of both laws are essentially the same, and with minor modifications, the radio provisions of the Communications Act of 1934 are still in effect.

23 There are a few other countries which can be cited as more liberal today because they are anarchic, with no regulatory policies or enforcement authority - Gambia and Somaliland, for example. There are also countries corrupt enough that anyone can do anything with radio for the right price.

${ }^{24}$ Receiver licensing is a particularly dubious practice, still widely employed in Europe and former British colonies to collect fees to support public broadcasting. (Schnepfleitner 2002) Note that this justification was invented long after the licensing of receivers began (in England, receiver licensing predates the creation of the BBC by nearly 20 years). Early receivers with vacuum tubes did in fact emit radio energy that could cause interference inadvertantly to nearby sets. However, receiver licensing in some European countries predates even that. Once again, the real reason for licensing was national security. As explained in an official report on radio in Europe for the US Postmaster General, abridged by Taussig (1922: 288), "In most European countries the amateur and novice have few rights. Radio is looked upon to a considerable degree as a weapon of espionage, and therefore suspicious European countries take good care to control every phase of it." Licensing gave governments a legal handle to make the reception of foreign 
spectrum access tends to come from the United States. However, the European Union became more active in promoting liberalization after adopting the Authorisation Directive ${ }^{25}$ (Directive 2002/20/EC) and even moreso after spectrum reform was made a top priority by the Information Society Directorate General. (Reding 2005)

\section{Radio License Exemption}

The International Radio Regulations are a binding treaty revised every few years at World Radio Conferences (WRCs) convened by the International Telecommunication Union (ITU). ${ }^{26}$ ITU Recommendations also strongly influence national regulations and laws, although it is hardly a mechanical process. The relationship between national and international spectrum policies is interactive - "bottom up" as well as "top down" and "peer-to-peer."

However, ITU-R Regulation S18.1 states:

"No transmitting station may be established or operated by a private person or by any enterprise without a license issued in an appropriate form and in conformity with the provisions of these Regulations by or on behalf of the government of the country to which the station in question is subject...” (International Radio Regulations 2004)

Many countries cite that as requiring the licensing of every radio transmitter as an ITU "treaty obligation." Indeed, S18.1 may sound like it forbids unlicensed radio transmitters, but a closer reading reveals significant subtleties. First, government stations do not need to be licensed - only those operated by "a private person or by any enterprise..." Restricting the obligation to license to specific operator groups implies the possibility of license exemption for others. Second, the text does not say that the license must be assigned to one specific station (an "individual" license). That leaves open the possibility of a generic license issued for any number of stations of a certain type (a "class" license). ${ }^{27}$ Third, this is an international regulation: stations whose signals do not cross a national border need not be bound by it if they are authorized by a government procedure other than licensing (equipment "type acceptance," for example).

Such interpretations might seem contrary to the main thrust of the rule, but they are not inappropriate. The wording of S18.1 has been carefully contrived to offer just this sort of elasticity to those wishing to exploit it. In fact, the US Government has been using such interpretations for the past 65 years to support the de-licensing of certain types of radio equipment:

broadcasts illegal, for example. This tradition has been updated in countries that license receive-only satellite terminals (Tabar 2002), and it might even be extended to personal computers someday, if the online audience for programs streamed by public broadcasters grows large.

${ }^{25}$ This Directive says that members of the European Community should apply "the least onerous authorisation system" to providers of electronic communication services whenever possible. Individual licensing is to be used only when technically necessary - as a last resort.

${ }^{26}$ The ITU was created in 1932 by the merger of the International Telegraph Union and the International Radiotelegraph Union. (Codding 1952) A substantial collection of excerpts from the current ITU-R Radio Regulations is online at http://life.itu.int/radioclub/rr/frr.htm.

27 Some countries use "class licenses" to approximate license exemption. Usually these are countries that interpret ITU-R Regulation S18.1 so strictly that a requirement for all nongovernment stations to be licensed has been incorporated into their national radio law. However, while a "class license" can be minimally restrictive, it need not be so. In that way it is fundamentally different from license exemption, as shown by the Australian Communications Authority's "Explanatory Statement: Radiocommunications (Spread Spectrum Devices) Class Licence" (2002) According to that notice, ACA has the right to "include in a class licence any condition that it sees fit" or revoke the license at any time. 
Horvitz: Media Licensing, Convergence and Globalization - 12

"In 1938, the [US Federal Communications] Commission allowed devices employing relatively low level RF signals to be operated without the need for individual licensing as long as their operation caused no harmful interference to licensed services... Typical kinds of equipment operated under these regulations were wireless record players, carrier current communication systems (such as, campus radio systems) and remote control devices... In the 1960s through the 1980s, additional provisions were made under Part 15 [of the FCC's rules] to permit the operation of equipment such as wireless microphones, telemetry systems, garage door openers, TV interface devices (e.g., video cassette recorders), field disturbance sensors (e.g., anti-pilferage systems for retail stores), auditory assistance devices, control and security alarm devices, and cordless telephones.

"In 1985, Commission first authorized the operation of non-licensed spread spectrum systems in the $902-928 \mathrm{MHz}, 2400-2483.5 \mathrm{MHz}$, and 5725-5850 MHz bands under Part 15 of the rules at a power level of $1 \mathrm{~W}$ which was significantly higher than previously permitted unlicensed use in other bands...

"In its 1989 revision of the Part 15 rules, the Commission established new general emission limits in order to create more flexible opportunities for the development of new unlicensed transmitting devices. These more general rules allow the operation of unlicensed devices for any application provided that the device complies with specified emission limits..." (Spectrum Policy Task Force 2002:7-8)

Eliminating the time and effort needed to apply for a license, the cost of buying frequencies at auction or the expertise needed to petition the government for a new service allocation obviously reduces the difficulty and risk of introducing new products and shortens the time-to-market. But the flood of innovations unleashed by the availability of license-exempt radio bands is still startling. Over 6 billion dollars of license-free devices were sold in the US in 2002 - before the Wi-fi boom had even developed a full head of steam. ${ }^{28}$ (Carter, Lahjouji, McNeil 2002:iv)

However, the ITU has - until recently - treated unlicensed devices as third-class citizens of the spectrum - like vermin notable only for posing a risk of interference to licenseholders. Yet now that they are the fastest growing part of the consumer electronics market, and the public clearly finds them interesting, convenient and necessary, even the stodgy ITU has begun to appreciate them. Adapted to survival in the "ISM jungle"29 they generally use spectrum much more efficiently than licensed stations, they are less susceptible to interference and cause less of it. With demand for frequencies growing constantly, they point the way toward better band-sharing solutions for everyone.

The World Radio Conference of 2003 established a primary global allocation for license exempt radio local area networks (RLANs). (WRC-03 Resolution 229 [COM5/16] 2003) That breakthrough was followed by a project to revise the ITU's recommendation for the regulatory treatment of short-range radio devices. Part of the latest draft reads:

“...The ITU Radiocommunication Assembly... recommends... that these devices should not be restricted more than necessary in their use... There is a general agreement that when the efficient use of the frequency spectrum is not at risk and as long as harmful

\footnotetext{
28 The US Congress made a remarkable affirmation of the value of license exempt devices back in 1997 when it ordered the FCC not to establish new licensed services "in bands allocated or authorized for unlicensed use..." if the licensed services "would interfere with operation of [unlicensed] end-user products..." (Balanced Budget Act of 1997, cited in Feld and Schwartzman 2004: 6)

${ }^{29}$ Industrial, Scientific and Medical (ISM) applications are identified in ITU-R Regulation 5.138 as being "subject to special authorization" - that is, subject to a regime other than individual licensing, a special case which must be authorized by a responsible agency of government. (International Radio Regulations 2004)
} 
interference is unlikely, the installation and use of radio equipment may be exempt from a general licence or an individual licence..." (CEPT 2005: 16)

In December 2004 the ITU's annual Global Symposium for Regulators convened in Geneva to discuss "Licensing in an Era of Convergence." Hundreds of telecom regulators from around the world attended and they unanimously endorsed a set of "Best Practice Guidelines for the Promotion of Low Cost Broadband and Internet Connectivity." It included this passage:

"We further encourage innovative approaches to managing the spectrum resource such as the ability to share spectrum or allocating on a license-exempt non-interference basis..." (Global Symposium for Regulators 2004)

Which led the Washington-based newsletter Communications Daily to headline their coverage of the GSR, "World Regulator Summit Endorses Unlicensed Spectrum." (Buskirk 2004) To ice the cake, the ITU's annual review of Trends in Telecommunication Reform was published in time for the global symposium. According to the Executive Summary,

“...more and more policy-makers are questioning the utility of licensing and demanding that licences be adapted to achieve policy goals without hindering market development and technological advancement... The allocation of spectrum for licence-exempt use is increasingly viewed as a catalyst for the development of more efficient and cost-effective wireless technologies. By late 2004, 55 countries had allocated spectrum for unlicensed use..." (International Telecommunication Union 2004a:14-16)

The ITU's favorable new attitude toward unlicensed radio will inevitably influence governments around the world, though it may be too soon to declare victory, put our feet on the table and watch the chains fall off transmitters all by themselves. Many countries - perhaps a majority have domestic laws requiring individual and class licenses, and decades of traditions, precedents, contracts and business arrangements based on those laws. Licenseholders, too, are not mere victims of an authoritarian system. They have benefitted greatly from protection against interference and competition - with the cost of the protection being borne by others - and as we saw with the US Radio Act of 1927, they actively supported the imposition of restrictive licensing. They, and their lawyers and lobbyists, will surely fight to preserve their privileges.

No, it will take years for change to occur. To the extent that the ITU itself adopts a more flexible approach to spectrum management, their guidance to member states is likely to become less specific and more voluntary - so that countries not wanting to de-license won't be forced to. However, their recent statements confirm that radio licensing is not technically necessary in all cases. In some cases it is detrimental to technological progress and to achieving universal access to communication services.

If licensing is neither desirable nor technically necessary in all cases, then other justifications for the practice need to be re-examined critically as well. That is what this text tries to begin. In telegraphy we saw that licensing was introduced to dole out and deny advantages in the power games of international rivalry. That game continued into the era of wireless telegraphy, leading to the dogma of national sovereignty over radio. ${ }^{30}$ With broadcasting, licensing returned to its earlier role as a way for the state to control public access to content and to structure the market economically. If further challenges to the legitimacy of radio licensing as a tool of public policy are to make progress after the highest authority in technical regulation has cast doubt on the most widely accepted argument, a new strategy will be needed. As we have tried to emphasize, the narrow view of licensing as only technically justified is historically false. That view limits our understanding of licensing's continuing appeal and keeps us ignorant of other grounds on which it can be challenged or supported. National security arguments still attract governments in Asia,

30 Anti-globalization protestors take note: nationalism was much more lamentable and cruel. 
while content controls are popular in the Middle East. Countering those will be difficult and technical arguments alone are not likely to be effective.

One tool that might useful, at least in some contexts, is the human rights argument. We used this for the first time last February in an Ofcom consultation (Open Spectrum UK 2005), and it was quickly copied by an Irish group during a ComReg consultation (Scagaire 2005). We then asked the London-based organization Article 19 to research the legal aspects and they produced a very helpful analysis entitled "The legitimacy of licence requirements for the use of wireless communications devices" (Simons 2005) The author, Daniel Simons, points out that the "International Covenant on Civil and Political Rights" (ICCPR) is a binding treaty ratified by over 150 States. Article 19 of the ICCPR says, in part:

"2. Everyone shall have the right to freedom of expression; this right shall include freedom to seek, receive and impart information and ideas of all kinds, regardless of frontiers, either orally, in writing or in print, in the form of art, or through any other media of his choice.

"3. The exercise of the rights provided for in paragraph 2 of this article carries with it special duties and responsibilities. It may therefore be subject to certain restrictions, but these shall only be such as are provided by law and are necessary:

(a) For respect of the rights or reputations of others;

(b) For the protection of national security or of public order (ordre public), or of public health or morals."

This establishes a 3-part test of whether a restriction on freedom of expression is legitimate, or whether it violates human rights: (1) the restriction must be based on an enacted law or regulation; (2) it must have a legitimate purpose (national security, protecting the rights of others, maintaining public health or morals, etc.); and finally, (3) the restrictions must be necessary to achieve the intended purpose.

The question of necessity links back to the ITU's recommendation on license exemption for short-range devices, quoted above, and it is likely to be the key question to which both advocates and opponents of change must respond: e.g. when is radio licensing necessary to protect the rights of others? Very likely, there will be no "bright line" separating necessary from unnecessary licensing in many cases. Therefore, the effectiveness of the arguments framed by the advocates of each side will determine where the boundary is placed. According to Simons,

"Licence requirements applicable to all owners of a particular type of [wireless] device generally contravene international law, because they do not serve a legitimate purpose; mere ownership of a particular instrument does not normally present any risk of societal harm. On the other hand, no sweeping assessment can be made of the legitimacy of licencing regimes for the use of wireless communications devices, and a case-by-case analysis is necessary...

"Because higher power levels generally correspond to greater risks of interference, licencing of traditional high-power uses of the radio spectrum is often 'necessary' under the balancing test set out above. On the other hand, the need for regulation of modern consumer devices is on the whole far smaller. Not only do they operate at lower power levels, they are also frequently equipped with novel technologies which enable them to partly compensate the effects of interference...

"There is a risk that force of habit might lead some telecommunications regulators to over-regulate modern, low-interference devices, imposing licencing regimes or other 
restrictions which do not meet the necessity test. Most States are exploring alternative ways of accomplishing the goal of preventing interference with regulatory tools that are less restrictive of freedom of expression. One of these tools is the opening up of ranges of the spectrum for shared use, and the adoption of a certification system for devices which transmit data within these ranges... The availability of regulatory tools like this to guarantee 'public order in the airwaves' means that the imposition of a licence requirement for modern types of devices will often no longer prove justifiable when evaluated under the 'necessity' test..."

Obviously, a human rights argument will not be effective everywhere - certainly not in countries that routinely violate or ignore human rights, nor in situations where national security or public safety arguments are more compelling. But it is an additional tool that recognizes licensing as more than a technical issue, and which builds on the ITU's acknowledgement that despite Regulation S18.1, radio licensing is not always necessary or desirable.

For nearly a century, governments have imposed detailed limits on the use of radio - who can use what frequencies and waveforms, at what power levels, in which locations, for what purposes. Licenses summarize these controls for specific users or stations. State control of radio use goes far beyond what is accepted for other media, (publishing, photography, Internet, speech, etc.). Most people considered this necessary to control interference, while others felt that broadcasting was too powerful a social influence to be left unregulated.

Recently, there has been explosive growth in short-range, personal uses of radio - Bluetooth, Wi$\mathrm{Fi}$, cordless phones, etc. The arguments traditionally used to justify radio licensing seem inappropriate for such low-power devices. In fact, government regulation of purely personal, inhome communications is unnecessarily intrusive and politically risky. Many countries now allow some short-range wireless devices to be used without a license in specific bands. In general, smarter radios go a long way toward solving problems that once seemed to require rigid government controls, giving rise to the "open spectrum" movement.

At the same time, digitalisation and the widening use of TCP/IP make it possible to transmit nearly any content through any channel. We use our mobile phones to take photographs, send text messages and watch videoclips. Our cable television networks provide Internet access. Our personal computers capture podcasts, create animations and archive everything from email to porn films. Seeping out of their original contexts, dissimilar media traditions now mix and clash in interconnecting, hybrid networks. In this situation, it is crucially important to the future of human communication which regulatory norms emerge as default choices and dominant models. Will it be broadcasting, telephony, publishing, Internet or ordinary speech that sets the tone for communications policy in the age of ubiquitous networks? Which regulatory approach do we want to set the tone? 
Horvitz: Media Licensing, Convergence and Globalization - 16

\section{List of References}

Andersson-Skog, Lena. (2000) "National Patterns in the Regulation of Railways and Telephony in the Nordic Countries to 1950" Scandinavian Economic History Review, 48:2, 30-46 [cited in Wallsten 2001].

Australian Communications Authority (2002) "Explanatory Statement: Radiocommunications (Spread Spectrum Devices) Class Licence" [online] available at <http://www.acma.gov.au/acmainterwr/aca home/legislation/radcomm/acts/radcom/es spread_2002.pdf $>$ [23 June 2005]

"Balanced Budget Act of 1997" (1997) Pub.L. 105-33, Section 3002(c)(1)(C)(v) Washington, DC USA: Government Printing Office [cited in Feld 2004]

Banning, W. P. (1946) Commercial Broadcasting Pioneer: The WEAF Experiment, 1922-1926 Cambridge, Massachusetts USA: Harvard University Press.

Bennett, A.R. (1895) The Telephone Systems of the Continent of Europe London, England: Longmans, Green, and Co. [cited in Wallsten 2001]

Buskirk, H. (2004) “World Regulator Summit Endorses Unlicensed Spectrum" Communications Daily, 24(239):2 [14 December] Washington, DC USA: Warren Communications News [online] available at 〈http://www.volweb.cz/horvitz/os-info/GSR-unlicensed.html〉

Carter, K. R., Lahjouji, A., and McNeil, N. (2003) Unlicensed and Unshackled: A Joint OSPOET White Paper on Unlicensed Devices and Their Regulatory Issues Washington, DC USA: Federal Communications Commission, Office of Strategic Planning and Policy Analysis [online] available at http://hraunfoss.fcc.gov/edocs_public/attachmatch/DOC234741A1.pdf [20 May 2004]

Caslon Analytics (2005) "Censorship and Free Speech Guide: Censorship of Performance and Street Life" [online] available at <http://www.caslon.com.au/censorshipguide14.htm> [13 April 2005]

Casson, H. N. (1910) The History of the Telephone Chicago, Illinois USA: A. C. McClurg \& Co., Chicago [online] available at $<$ http://www.telephonetribute.com/the history of the telephone.html $>$ [2 September 2005]

Catholic Encyclopedia (1913) "Censorship of Books (Censura Librorum)" New York, USA: Encyclopedia Press Inc. [online] available from $\langle$ http://www.newadvent.org/cathen/-

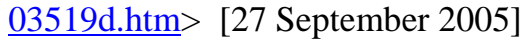

CEPT (2005) "Preliminary Draft Revision of Recommendation ITU-R SM.1538-1: Technical and operating parameters and spectrum requirements for short range radiocommunication devices (Question ITU-R 213/1)" 4 July 2005 [online] available from $<$ http://ntiacsd.ntia.doc.gov/ussg1/uswp1b/WP\%201B\%20Documents/R03-WP1B-C0062!!MSW-E.doc >

Chartrand, H. H. (2000) "Copyright CPU: Creators, Proprietors \& Users," Journal of Arts Management, Law \& Society 30:3 [online] available from < http://www.culturaleconomics.atfreeweb.com/cpu.htm> [10 June 2005]

Clark, K. (1931) International Communication: The American Attitude. New York, NY:

Columbia University Press. [cited in Feldman 1975] 
Codding, Jr., G. A. (1952) The International Telecommunication Union Leiden, Netherlands: E. J. Brill (Reprinted by the New York Times/Arno Press in 1972)

Coliver, S. (1993) Article 19 Freedom of Expression Handbook: International Comparative Law, Standards and Procedures. London, England: Article 19.

Communications Act of 1934 (as amended by the Telecommunications Act of 1996) (1934 et seq.) Washington, DC USA: Government Printing Office [online] available at 〈http://www.fcc.gov/Reports/1934new.pdf>

"Directive 2002/20/EC of the European Parliament and of the Council of 7 March 2002 on the authorisation of electronic communications networks and services" [the Authorisation Directive] Brussels, Belgium: Official Journal L108, 24 April 2002 [online] available at <http://europa.eu.int/information_society/topics/telecoms/regulatory/new_rf/ documents/1 10820020424en00070020.pdf $>$ [22 August 2004]

Eisenstein, Elizabeth L. (1980) The Printing Press as an Agent of Change. Cambridge, England: Cambridge University Press.

Ernst, Morris L. (1926) “Who Shall Control the Air?” The Nation 122:3172 (21 April)

EuroActiv.com, "LinksDossier: TWF - Television Without Frontiers" [online] available at $<$ http://www.euractiv.com/Article?tcmuri=tcm:29-117550-16\&type=LinksDossier > [15 September 2005]

Fagen, M. D. (ed.) (1976) A History of Science and Engineering in the Bell System Murray Hill, New Jersey USA : Bell Telephone Laboratories, I, 384 [cited in Pool 1983]

Feld, H. and Schwartzman, A. (2004) "A General Overview of the FCC's Authority to Create the Existing Part 15 Rules an [sic] Their Relationship to Licensed Services - Ex Parte Presentation of the Media Access Project relevant to ET Docket Nos. 03-108, 03-237, 04151, and 04-186" [online] available at <http://gullfoss2.fcc.gov/prod/ecfs/retrieve.cgi?native or_pdf=pdf\&id_document=6516885224> [22 December 2004]

Feldman, M. L. B. (1975) The United States in the International Telecommunication Union and in Pre-ITU Conferences. Baton Rouge, Louisiana: M. L. B. Feldman, publisher.

Gabb S. (1992) The Case Against Sex Censorship: A Conservative View London, England: Libertarian Alliance

Global Symposium for Regulators (2004) "Best Practice Guidelines for the Promotion of Low Cost Broadband and Internet Connectivity" Geneva, Switzerland: International Telecommunication Union [online] available at $<$ http://www.itu.int/ITU-D/treg/Events/Seminars/2004/GSR04/consultation.html> [23 December 2004]

Government of Australia (1999) "Broadcasting Services Amendment (Online Services) Act" [online] available from <http://scaleplus.law.gov.au/html/comact/10/6005/0/CM$\underline{000060 . h t m}>$ [5 September 2005]

Government of Honduras (1995) "Ley Marco del Sector de Telecomunicaciones," Decreto No. 185-95 \& Decreto No. 118-97 [online] available at <http://www.conatel.hn/LEY MARCO TELECOMUNICACIONE.HTM> [1 May 2005] 
Horvitz: Media Licensing, Convergence and Globalization - 18

Government of the People's Republic of China (2004) "Measures on the Administration of Broadcasting Audio/Visual Programs over the Internet or Other Information Networks (2003.01.07)" - translated from Chinese by the [US] Congressional-Executive Commission on China [online] available from <http://www.cecc.gov/pages/virtualAcad/exp/explaws.php> [10 September 2005]

--- (2000) "Interim Provisions on the Administration of Internet Websites Engaged in News Posting Operations (2000.11.01)" - translated from Chinese by the [US] CongressionalExecutive Commission on China [online] available from <http://www.cecc.gov/pages/virtualAcad/exp/explaws.php> [10 September 2005]

Government of Vietnam (2002) "Decision 27/2002/QD-BVHTT: Regulation on the management and licensing of information provision and website establishment on the Internet." Hanoi, Vietnam: Ministry of Culture and Information, 10 October 2002 [online] available from <http://www.ilr-moj.ac.vn/law/en/2001_to_2010/2002/200210/200210100001_en/view> [3 August 2005]

Hazlett, T. W. (2001) “The Wireless Craze, the Unlimited Bandwidth Myth, the Spectrum Auction Faux Pas, and the Punchline to Ronald Coase's 'Big Joke': An Essay on Airwave Allocation Policy" Harvard Journal of Law \& Technology 14(2): 335-469 [online] available at $\langle\underline{\mathrm{http}}$ ://jolt.law.harvard.edu/articles/pdf/14HarvJLTech335.pdf> [16 April 2005]

Holcombe, A. N. (1911) Public Ownership of Telephones on the Continent of Europe. Boston, Massachusetts USA and New York, NY USA: Houghton Mifflin Company [cited in Wallsten 2001]

Howeth, L. S. (1963) History of Communications-Electronics in the United States Navy Washington, DC USA: Government Printing Office

Intellect (2005) "Review of the Television Without Frontiers Directive: Intellect Response to European Commission Issue Papers.” [online] available from <http://europa.eu.int/comm/avpolicy/revision-tvwf2005/docs/ip1-intellect.pdf> [25 September 2005]

International Communications Round Table (ICRT) (1996) "Resolution opposing application of the Television Without Frontiers Directive to the Internet, electronic publishing, online services and other new electronic services" Brussels, Belgium [online] available from 〈http://www.icrt.org/pos_papers/1996/960300_OB.pdf>

International Covenant on Civil and Political Rights (ICCPR) (1976) New York, NY USA: United Nations [online] available at 〈http://www.unhchr.ch/html/menu3/b/a_ccpr.htm $>$

International Radio Regulations (2004) “Article 18: Licenses" Geneva, Switzerland: International Telecommunication Union [online] available at $<\underline{\text { http://life.itu.int/radio- }}$ club/rr/art18.htm> [12 September 2004]

International Telecommunication Union (1965) From Semaphore to Satellite Geneva, Switzerland: International Telecommunication Union (cited in Feldman 1975:4)

--- (2004a) Trends in Telecommunication Reform 2004/05: Licensing in an era of convergence Geneva: International Telecommunication Union [online] Executive Summary available at $\langle$ http://www.itu.int/ITU-D/treg/publications/Trends04_summary.pdf $>$

--- (2004b) “Annex 5 to WP 1B Chairman's Report: Working Document Towards the Draft Report to the Director, Radiocommunication Bureau in Response to Resolution 951 
(WRC-03)" - Document 1B/TEMP/12(Rev.1), 23 November Geneva: International Telecommunication Union [online] available at $<$ http://ntiacsd.ntia.doc.gov/ussg1/ uswp1b/WP\%201B\%20Documents/R03-WP1B-C-0050!!MSW-E/R03-WP1B-C0050!R1-N5!MSW-E.doc> [1 March 2005]

"Invitation to Bid on the Privatization of 'Antenna Hungaria' - Hungarian Radiocommunications Corporation" (2005) Állami Privatizációs és Vagyonkezelõ Részvénytársaság Budapest, 11 April 2005 [online] available at <http://www.apvrt.hu/pages/p_2285.html> [22 September 2005]

Karlekar, K. D. (ed.) (2005) Freedom of the Press 2005: A Global Survey of Media Independence. Washington, DC: Freedom House. [online] available from $\langle$ http://www.freedomhouse.org/research/pressurvey/fop05.pdf>

Lackman, E. M. "Clearing the Airwaves: Will the FCC's Crackdown on Indecent Broadcasts Put a Chill on Protected Speech?" New York State Bar Association Entertainment, Arts and Sports Law Journal 15(2) [online] available at <http://www.loeb.com/CM/Articles/easllackman-summer04.pdf> [23 September 2005]

Lahav, P. (ed.) (1985) Press Law in Modern Democracies: A Comparative Study. New York, NY: Longman Press.

MacDougall, R. (2005) "Long Lines: AT\&T and the Spectacle of the Transcontinental Telephone Network" Presented at the History of Business Conference "Reinvention and Renewal," Minneapolis, Minnesota, 20 May [online] available at $\langle\underline{\mathrm{http}: / / \mathrm{www} . \mathrm{h}-}$ net.org/ business/bhcweb/ annmeet/macdougall.pdf> [25 September 2005]

"Majority of Corruption Cases in China Linked to Licensing: Official," People's Daily, 30 August 2003 [online] available from <http://english.people.com.cn/200308/30/eng20030830_123408.shtml $>$ [12 August 2005]

McIver Jr., W. J., and Birdsall, W. F. (2002) "Technological Evolution and the Right to Communicate: The Implications for Electronic Democracy," presented at the Euricom Colloquium: Electronic Networks \& Democracy, 9-12 October, Nijmegen, Netherlands [online] available from $<$ http://baserv.uci.kun.nl/ jankow/Euricom/papers/McIver\%20\&\%20Birdsall.pdf $>$ [2 May 2005]

Media Law and Policy Institute (2002) "Explanatory Notes to the Draft Statute, 'On Amending the Federal Statute "On Communications." Moscow, Russian Federation. [online] available from $\langle$ http://www.medialaw.ru/e pages/research/memorandumtele.htm>

"Ministerio Público investiga a CANARA y Oficina de Control de Radio," Informa-Tico.com, 9 June 2005. [online] available from $<$ http://www.informa-tico.com/php/expat.php?-

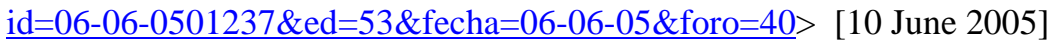

Myanmar State Law and Order Restoration Council (1996) "Law No. 10/96: The Computer Science Development Law" Rangoon, Myanmar: 20 September 1996. [online] available at $\langle$ http://www.myanmar.com/gov/laws/computerlaw.html $>$

Neto, I., Best, M. and Gillett, S. (2004) "License-Exempt Wireless Policy: Results of an African Survey," presented at the ITS Conference, Berlin, Germany, 4-7 September [online] available at $<$ http://itc.mit.edu/itel/docs/2004/ITS_paper_neto best_gillett.pdf $>$

Open Spectrum UK (2005) “Open Spectrum UK Response to Ofcom’s “Spectrum 
Horvitz: Media Licensing, Convergence and Globalization - 20

Framework Review" Consultation" (15 February) [online] available at <http://www.ofcom.org.uk/consult/condocs/sfr/responses/openspectrum.pdf $>$ [1 March 2005]

Poole, Ithiel de Sola (1983) Technologies of Freedom: On Free Speech in an Electronic Age. Cambridge, Massachusetts: Belknap Press.

Public Law No. 264 (1912) “An Act to Regulate Radio Communication” (The Radio Act of 1912) Washington, DC USA: US Congress, 13 August [online] available at <http://earlyradiohistory.us/1912act.htm> [23 September 2005]

Public Law No. 632 (1927) "An Act for the regulation of radio communications, and for other purposes" (The Federal Radio Act of 1927) Washington, DC USA: US Congress, 23 February [online] available at 〈http://showcase.netins.net/web/akline/pdf/1927act.pdf > [3 September 2005]

Prime, S. I. (1875) The Life of Samuel F. B. Morse New York, NY: D. Appleton (New York Times/Arno Press Inc. reprint, 1974)

Reding, Viviane (2005) "Spectrum reforms, the Lisbon strategy and the i2010 initiative," address to the 7th meeting of the Radio Spectrum Policy Group, Brussels, Belgium, 16 June (SPEECH/05/374) [online] available at $<$ http://europa.eu.int/rapid/pressReleasesAction.do?reference=SPEECH/05/374\&format=HTML\&aged=1\&language=EN\&guiLan guage $=$ en $>$ [20 June 2005]

Richards, E. (2005) “The Future Evolution of Television, Radio and Telecoms" London, England: Ofcom Annual Lecture at the Westminster Media Forum, 20 July [online] available at $\langle$ http://www.ofcom.org.uk/media/speeches/2005/07/nr_20050720 $>$

Scagaire (2005) “Tuning in to the Public's Voice: A Submission in Response to ComReg's Consultation on Radio Spectrum Management" (7 March) [online] available at <http://funferal.org/mt-archive/Scagaire0501ComReg.pdf > [7 March 2005]

Schnepfleitner, R. (2002) "The use of funds collected for 'Public Service Broadcasting"” Vienna, Austria: Rundfunk \& Telekom Regulierungs GmbH [online] available at <http://www.rtr.at/web.nsf/lookuid/BDA796C1F567E31AC1256DC80035467C/\$file/Stu dieRundfunkgeb\%FChren.pdf > [10 June 2004]

Schreiner, G. A. (1924) Cable and Wireless and Their Place in the Foreign Relations Boston, Massachusetts USA: The Stratford Company. [cited in Feldman 1975]

Simons, D. (2005) "The legitimacy of licence requirements for the use of wireless communications devices" London, England: Article 19 [online] available at $\langle$ http://www.volweb.cz/horvitz/os-info/article19.doc> [1 June 2005]

Singapore Media Development Authority (2001) "Broadcasting (Class Licence) Notification" [online] available at $\langle$ http://www.mda.gov.sg/wms.file/mobj/mobj.487.ClassLicence.pdf> [23 May 2004]

Spectrum Policy Task Force (2002) Report of the Unlicensed Devices and Experimental Licenses Working Group Washington, DC USA: US Federal Communications Commission [online] available at $\langle$ http://www.fcc.gov/sptf/files/E\&UWGFinalReport.pdf> [20 October 2004]

Stanhope Centre for Communications Policy Research (2003) Study of Media Laws and 
Policies in the Middle East and Maghreb. London, England. [online] available at $\langle\underline{\text { http://www.internews.org/arab_media_research/final_report_april_25_2nd.pdf }>}$

Tabar, M.-D. (2002) Printing Press to Satellite: A Historical Case Study of Media and the Arab State Washington, DC USA: Graduate School of Arts and Sciences, Georgetown University [online] available at 〈http://cct.georgetown.edu/thesis/MaryDeniseTabar.pdf $>$

Taussig, C. W. (1922) "Radio in European Countries" - Chapter XX in The Book of Radio. New York, NY USA/London, England: D. Appleton and Co. [online] available at $<$ http://earlyradiohistory.us/1922euro.htm> [5 September 2005]

United States Code, Title 18, Section 1464 - Crimes and Criminal Procedure [online] available at $\langle$ http://www4.law.cornell.edu/uscode/html/uscode18/usc sup 01 18.html $>$ [28 September 2005]

US Constitution [online] available at $\lfloor$ http://www.house.gov/Constitution/Constitution.html> [29 September 2005]

US Federal Communications Commission, Enforcement Bureau (2004) "Obscene, Profane \& Indecent Broadcasts" 7 March [online] available at <http://www.fcc.gov/eb/broadcast/opi.html> [28 September 2005]

--- (2005) "Memorandum Opinion and Order - In the Matter of Various Complaints Regarding CNN's Airing of the 2004 Democratic National Convention (File No. EB-04-IH-0329)" Washington, DC USA: adopted and released 17 March [online] available at <http://www.fcc.gov/eb/Orders/2005/DA-05-717A1.html> [23 September 2005]

Wallsten, S. J. (2001) "Ringing in the 20th Century: The Effects of State Monopolies, Private Ownership, and Operating Licenses on Telecommunications in Europe, 1892-1914." Policy Research Paper number WPS 2690 Washington, DC: The World Bank Group [online] available at $<$ http://ssrn.com/abstract $=281092>$

Weare, C., Levi, T., and Raphael, J. (2001) "Media Convergence and the Chilling Effect of Broadcast Licensing." Harvard International Journal of Press/Politics, 6 (3): 47-70. [online] available at 〈http://hij.sagepub.com/cgi/reprint/6/3/47>.[6 October 2004]

Webb, H. L.. (1910) The Development of the Telephone in Europe. London, England: Electrical Press Ltd. [cited in Wallsten 2001]

World Radio Conference (2003) "Resolution 229 [COM5/16]: Use of the bands 5150$5250 \mathrm{MHz}, 5250-5350 \mathrm{MHz}$ and $5470-5725 \mathrm{MHz}$ by the mobile service for the implementation of wireless access systems including radio local area networks" Geneva, Switzerland: International Telecommunication Union [online] available at $<$ http://www.med.govt.nz/rsm/planning/srd/discussion/discussion-14.html $>$ [5 November 2004]

Yavorsky, V. (2003) "A Law that Can Stamp Out the Last Vestiges of Independent Radio and TV in Ukraine," Telecriticism, 14 May [online] available at <http://www.telekritika.kiev.ua/comments_eng/?id=8659> [10 September 2005]

Young, D., and Beck, L. (2005) "China tightens noose with new Web rules," Reuters, 26 September [online] available at $<$ http://today.reuters.com/news/NewsArticle.aspx?type= internetNews\&storyID=2005-09-26T121230Z 01_YUE371618 RTRUKOC_0_USCHINA-INTERNET.xml> [26 September 2005] 